\title{
Technical Efficiency of Pineapple Production in Osun State, Nigeria
}

\author{
O. Adegbite, I. B. Adeoye
}

National Horticultural Research Institute, P. M. B 5432, Idi-Ishin, Ibadan.

\begin{abstract}
Pineapple is one of the most important fruits in Nigeria and it had been identified that the country has comparative advantage in its production. However, there is need for empirical studies on the technical efficiency of its production. This paper presents the analysis of technical efficiency of pineapple production in Osun state, Nigeria using stochastic frontier production function and resource use efficiency. Primary data was collected from 120 pineapple farmers using multi stage sampling technique. Results revealed that quantity of suckers and labour used in pineapple production was positive and significant at 5\% while farm size was significant at $1 \%$. The returns to scale indicated that a unit increase in all the specified production inputs will lead to a more than proportionate increase in pineapple yield by $2.1 \%$. The mean technical efficiency of the pineapple farmers indicated that an average farmer could obtain about $93 \%$ of output from a given mix of inputs. The estimated gamma parameter revealed that $81.4 \%$ of the variation in output among the pineapple farmers was due to disparities in technical efficiency. Resource use efficiency indicated underutilization of suckers and overutilization of other specified production inputs. The study therefore recommends that farmers should cut down the use of resources that were over utilized and increase the quantity of suckers used in the production of the commodity for optimal productivity.
\end{abstract}

\section{Keywords:}

Pineapple productivity, technical efficiency, stochastic frontier, Osun state.

\section{Introduction}

In Nigeria, horticultural crops such as pineapple have a significant place. These crops not only contribute to the share of agriculture in national economy, but possess a great potential and comparative advantage to compete in the liberalized economy (Oguniyi, Oladejo, 2011). Pineapple has been identified as one of the horticultural crops with enormous potentials for nutritional and health benefits, foreign exchange earnings, industrial growth and development (Joy, 2010; Fawole, 2008; Fakayode et al., 2012). According to Ullah, (1980), the development of industrial uses of the crop will stimulate large scale production of the crops and enhance diversification of entrepreneurs to site processing plants in the rural areas which will improve the quality of life of the rural population and reduce the rate of rural-urban migration. Also the expansion of local industries for Pineapple can increase national income as well as provide higher incomes for farmers involved in its production (Fawole, 2008). In Nigeria, pineapple production is the main source of income for many farmers (Baruwa, 2013) hence they depend solely on it for their means of livelihood.
Among the top ten pineapple producing countries in the world, which include: Thailand, Costa Rica, Brazil, Philippines, Indonesia, India, Nigeria, China, Mexico and Colombia, Nigeria had the lowest productivity of 7.9 tons/ha when compared with the other nine top producers thereby, contributing a small share (6.1\%) of the world pineapple production (FAOSTAT, 2012). An analysis of the trends in Nigeria's productivity growth on agricultural crops showed that technical inefficiency was mainly responsible for poor productivity performance (Adenikinju, 2005). The inefficiency problem was attributed to factors such as use of low input technologies, lack of knowledge of high input technologies and poor farm management skills, poor extension services, unavailability and high cost of inputs (Anyanwu, Obasi, 2010). The inefficient allocation of these resources by farmers had made Nigerian agriculture to remain at the traditional and rudimentary level (Michael, 2011). In addition, the productivity of these farmers was often affected by factors such as age, cropping patterns, years of farming experience and lack of access to credit which tend to impact negatively on productivity and efficiency (Obasi et al., 2013). This trend must 
be reversed in order to enable Nigeria achieve its potentials and meet the goals of the Agricultural Transformation Agenda. One way peasant farmers (small scale pineapple producers) can achieve sustainable agricultural development is to raise the productivity of their farm by improving efficiency within the limits of the existing resource base and available technology (Amarasuruya et al., 2010).

Technical efficiency is a major component of productivity used in measuring farm performance (Lawal, 2007). It refers to the achievement of the maximum potential output from a given amounts of inputs, taking into account physical production relationships (Cesaro et al., 2009). Technical efficiency can be output, reflecting the maximum output that can be achieved from each input, or alternatively representing the minimum input used to produce a given level of output (Ogunniyi and Oladejo, 2011). Analysis of technical efficiency in agriculture has received particular attention in developing countries like Nigeria because of the importance of productivity growth in agriculture for overall economic development (Ogunlari, 2009). Gains in agricultural output through the improvement of efficiency levels are becoming particularly important nowadays since opportunities to increase farm production by bringing additional virgin land into cultivation or by increasing the utilization of the physical resources have been diminishing (Lawal, 2007). Furthermore, for individual farms, gains in efficiency are of great substance in periods of financial stress since efficient farms are more likely to generate higher incomes and thus, stand a better chance of surviving and prospering (Gil et al., 2007).

Previous studies on pineapple in Nigeria had been skewed towards market efficiency which includes those of Oladapo et al. (2007) who examined the market margin and spatial pricing efficiency of pineapple in Nigeria. Adesope et al. (2009) analyzed the Economics of group marketing of pineapple in selected markets of Osun state, Nigeria and Amao et al., (2011) analyzed the Economics of Pineapple marketing in Edo and Delta states, Nigeria. Empirical studies on the use of Stochastic frontier production function in determining efficiency in Horticultural crop production in Nigeria were also elaborated. Okon et. al., (2010) analyzed the technical efficiency and its determinants in Garden egg (Solanum spp) production in Uyo Metropolis, Akwa Ibom State, Nigeria, and Lawal, (2007) analyzed the efficiency of sweet orange production among small scale farmers in Osun State, Nigeria. However, no study had been documented for the technical efficiency of pineapple production in Nigeria to the best of author's knowledge. The study therefore examines the level of technical efficiency of pineapple production in Osun State, Nigeria in order to derive policy measures that will increase technical efficiency and thus productivity using a stochastic frontier production function.

\section{Materials and methods}

\section{Study area}

The study was conducted in Osun state, Nigeria. The state lies between latitude $7^{\circ} 30^{\prime} \mathrm{N}$ of the equator and longitude $4^{\circ} 30^{\prime} \mathrm{E}$ of the Greenwich meridian on a land area of about $9,251 \mathrm{~km}^{2}$. Osun state shares boundaries with Kwara state in the North, Oyo state in the West, Ogun state in the South, Ondo and Ekiti states in the East (Osun State profile, 2004). The provisional 2006 population census result put the population of Osun state at 3,423,535 (NPC, 2006 Estimate), comprising mainly the Yoruba ethnic group. The people are predominantly peasant farmers cultivating mostly cash crops, food crops, fruits and vegetables as well as livestock production. According to Osun State Agricultural Development Programme (OSSADEP), the state is divided into three operational zones for administrative convenience Ife/Ijesa, Iwo and Osogbo comprising of 30 local governments areas (Osun state, 2009).

The state has 2 distinct climatic seasons, namely the dry and wet season. The natural vegetation comprises moist evergreen and semi-evergreen forest and secondary forest, with mean annual rainfall ranging between 1400 to $2000 \mathrm{~mm}$ while mean annual temperature ranges between $25^{\circ} \mathrm{C}$ to $27^{\circ} \mathrm{C}$ thereby providing a conducive climate for growing most tropical crops like pineapple. Osun state was selected for the study because of its high volume of pineapple production in South west Nigeria. A multi-stage sampling technique was used in selecting respondents for the study. The first stage involved purposive selection of 3 local government areas that are prominent for pineapple production in Osun state which include Ayedaade, Ife East and Ife North, the second stage involved selection of 2 communities in each local government and finally a total of 120 pineapple farmers were randomly selected from the 6 communities based on probability proportionate to size. 


\section{Method of data analysis}

Descriptive statistics was used to analyze the socioeconomic characteristics of the pineapple farmers while stochastic frontier production function (SFPF) was used to analyze the technical efficiency of the Pineapple farmers in the study area. The stochastic frontier production function independently proposed by Aigner et al. (1977) and Meeusen and Van Den Broeck (1977) assumes that maximum output may not be obtained from a given input or a set of inputs because of the inefficiency effects. The ideas of production function can be illustrated with a farm using $n$ inputs: $\mathrm{X}_{1}, \mathrm{X}_{2}, \ldots \ldots, \mathrm{X}_{\mathrm{n}}$, to produce output $Y$, efficient transformation of inputs into output is characterized by the production function $f(\mathrm{X})$, which shows the maximum output obtainable from various inputs used in production. It can be written as:

$Y_{i}=f\left(\mathrm{X}_{\mathrm{a}} ; \beta\right)+\varepsilon_{i}$

Where,

$Y_{i}$ is the quantity of yield,

$\mathrm{X}_{\mathrm{a}}$ is a vector of input quantities and,

$\beta$ is a vector of parameters

$\varepsilon \mathrm{i}$ is an error term defined as:

$\varepsilon_{\mathrm{i}}=\mathrm{V}_{\mathrm{i}}-\mathrm{U}_{\mathrm{i}}$

$i=1,2, \ldots n$ farms

$\mathrm{V}_{\mathrm{i}}$ is a symmetric component that accounts for pure random factors on production, which are outside the farmers' control such as weather, disease, topography, distribution of supplies, combined effects of unobserved inputs on production and $U_{i}$ is a one-sided component, which captures the effects of inefficiency and hence measures the shortfall in output $Y_{i}$ from its maximum value given by the stochastic frontier $f\left(\mathrm{X}_{\mathrm{a}} ; \beta\right)+V_{\mathrm{i}}$. The model is expressed as:

$Y_{i}=\exp \left(X_{i} \beta+V_{i}-U_{i}\right)$

The technical efficiency of production of the i-th farmer in the appropriate data set, given the levels of his inputs, is defined by:

$T E_{i}=\exp \left(-U_{i}\right)$

From equations (3) and (4), the two components $V_{i}$ and $U_{i}$ are assumed to be independent of each other, where $V_{i}$ is the two-sided, normally distributed random error $\left(V_{i} \sim N\left(0, \sigma_{v}^{2}\right)\right.$ and $U_{i}$ is the one-sided efficiency component with a half normal distribution $\left(U_{i} \sim \mid N\left(0, \sigma_{u}^{2}\right) . Y_{i}\right.$ and $X_{i}$ are as defined earlier.
The $\beta s^{\prime}$ are unknown parameters to be estimated together with the variance parameters.

The variances of the parameters, symmetric $V_{i}$ and one-sided $U_{i}$, are $\sigma_{v}{ }^{2}$ respectively $\sigma_{u}{ }^{2}$ and the overall model variance given as $\sigma^{2}$ are related thus:

$\sigma^{2}=\sigma_{v}{ }^{+} \sigma_{u}{ }^{2}$

The measures of total variation of output from the frontier, which can be attributed to technical efficiency, are lambda $\lambda$ and gamma $\gamma$ (Battese, Corra, 1977) while the variability measures derived by Jondrow et al., (1982) are presented by equations (4) and (5):

$\lambda=\frac{\sigma_{u}}{\sigma_{v}}$
$\gamma=\frac{\sigma_{u}{ }^{2}}{\sigma_{v}{ }^{2}}$

On the assumption that $V_{i}$ and $U_{i}$ are independent and normally distributed, the parameters $\sigma^{2}, \sigma_{v}^{2}, \sigma_{u}^{2}$, $\lambda$ and $\gamma$ can be estimated by method of maximum likelihood estimates (MLE), using the computer program FRONTIER Version 4.1 (Coelli, 1996).

The farm specific technical efficiency (TE) of the i-th farmer can be estimated using the expectation of $U_{i}$ conditional on the random variable $(i)$ as shown by Battese and Coelli (1995). The TE of an individual farmer is defined in terms of the ratio of the observed output to the corresponding frontier output given the available technology, that is:

$$
\begin{aligned}
T E_{i}=Y_{i} / Y_{i}^{*}= & \exp \left(X \beta+V_{i}-U_{i}\right)=\exp \left(-U_{i}\right) \\
& \exp \left(X \beta+V_{i}\right)
\end{aligned}
$$

So that: $\mathrm{O} \leq \mathrm{TE} \leq 1$

\section{Empirical stochastic frontier production function}

This was assumed to be specified by the Cobb Douglas frontier production function which is defined by:

$$
\begin{aligned}
\ln Y_{i}= & \ln \beta_{o}+\beta_{1} \ln X_{1}+\beta_{2} \ln X_{2}+\beta_{3} \ln X_{3}+\beta_{4} \ln X_{4} \\
& +V_{i}-U_{i}
\end{aligned}
$$

Where subscript $i$ refers to the observation of the i-th farmer, and

$Y_{i}=$ pineapple yield $(\mathrm{kg})$

$X_{1}=$ quantity of sucker/ha (number)

$X_{2}=$ quantity of fertilizer used $(\mathrm{kg} / \mathrm{ha})$ 
$X_{3}=$ total quantity of labour used (mandays)

$X_{4}=$ farm size under pineapple cultivation (ha)

$\beta_{i}$ 's $=$ parameters estimated

$\ln { }^{\mathrm{s}} \mathrm{s}=$ natural logarithms

$V_{i}=$ random errors which covers random effects on production outside the control of the decision unit

$U_{i}=$ technical inefficiency effect which are the result of behaviour factors which could be controlled by an efficient management (Xu, Jeffrey, 1995) and are assumed to be 0 independent of $\mathrm{V}$ ‘s.

In this study, the technical inefficiency was measured by the mode of the truncated normal distribution $\left(U_{j}\right)$ as a function of socio-economic factors (Yao, Liu, 1998). Where $U_{i}$ is defined by:

$U_{i}=\delta_{0}+\delta_{1} Z_{1}+\delta_{2} Z_{2}+\delta_{3} Z_{3}+\delta_{4} Z_{4}+\delta_{5} Z_{5}$

Where: $U_{i}=$ Technical inefficiency of the i-th farmer

$Z_{1}=$ gender $($ male $=1 ;$ female $=0)$

$Z_{2}=$ age of farmer (years)

$Z_{3}=$ years of education (years)

$Z_{4}=$ household size (number of persons)

$Z_{5}=$ years of farming experience (years)

These socioeconomic variables were included in the model to indicate the possible influence of the farmers" socioeconomic characteristics on the technical efficiencies of the farms (Adepoju, 2008). Correlation matrix was computed for the socioeconomic variables to test for multicolinearity among the variables. The efficiency of resource use was obtained from the estimated equation by comparing the marginal value product (MVP) with the marginal factor cost (MFC) of that input. The MVP of an input was obtained by:

$$
M V P_{x i}=M P P_{x i} * P
$$

Where $M P P_{x i}$ is the marginal physical product of input $x i$ and $P$ is the unit farm gate price of the output $(q)$. The MFC for inputs was defined as:

$M F C_{x i}=M P P_{x i} * r_{x i}$

Where $r_{x i}$ is the unit price of input $x i$. Whenever $M V P_{x i}>M F C_{x i}$ there is under utilization of resource $x i ; M V P_{x i}<M F C_{x i}$ there is over utilization of resource $x i$ and $M V P_{x i}=M F C_{x i}$ there is optimum utilization of resource $x i$.

\section{Results and discussion}

\section{Socio economic characteristics of the pineapple} farmers

Results from Table 1 revealed that $88.3 \%$ of the respondents were males which implied that pineapple production in the study area was largely dominated by the males.

\begin{tabular}{|c|c|c|}
\hline Socioeconomic variables & Frequency & Percentage \\
\hline \multicolumn{3}{|l|}{ Gender } \\
\hline Male & 106 & 88.3 \\
\hline Female & 14 & 11.7 \\
\hline Total & 120 & 100.0 \\
\hline \multicolumn{3}{|l|}{ Age } \\
\hline $0-20$ & 0 & 0 \\
\hline $21-40$ & 8 & 6.7 \\
\hline $41-60$ & 91 & 75.8 \\
\hline Above 60 & 21 & 17.5 \\
\hline Total & 120 & 100.0 \\
\hline \multicolumn{3}{|l|}{$\begin{array}{l}\text { Years of formal } \\
\text { education }\end{array}$} \\
\hline No formal education & 22 & 18.3 \\
\hline $1-5$ years & 11 & 9.2 \\
\hline $6-10$ years & 53 & 44.2 \\
\hline 11 years and above & 34 & 28.3 \\
\hline Total & 120 & 100.0 \\
\hline \multicolumn{3}{|l|}{ Household size } \\
\hline $1-5$ & 80 & 66.7 \\
\hline $6-10$ & 36 & 30.0 \\
\hline $11-15$ & 4 & 3.3 \\
\hline Total & 120 & 100 \\
\hline \multicolumn{3}{|l|}{ Farming experience } \\
\hline $1-5$ years & 5 & 4.2 \\
\hline $6-10$ years & 16 & 13.3 \\
\hline $11-15$ years & 70 & 58.3 \\
\hline Above 15 years & 29 & 24.2 \\
\hline Total & 120 & 100.0 \\
\hline \multicolumn{3}{|l|}{ Farm size } \\
\hline $0.1-1$ & 110 & 91.7 \\
\hline $1.1-5$ & 10 & 8.3 \\
\hline Total & 120 & 100.0 \\
\hline
\end{tabular}

This conforms to the findings of Fawole (2008) and Baruwa (2013) that pineapple 
production is male dominated. Majority of the farmers $(75.8 \%)$ were within 41-60 years age group with mean of 54 years. This implied pineapple farmers in the study area were relatively old which can affect the rate of technology adoption, productivity and efficiency. Results further revealed that $66.7 \%$ of the farmers had household size of 1-5 persons with mean of 5 persons. The small household size of the respondents had a great implication on family labour supply as large household size has tendency to supply more family labour and vice versa and are capable of readjusting to sudden changes in labour supply at peak periods of labour demand (Oluyole et al, 2013). Most of the respondents (58.3\%) had 11-15 years of experience in Pineapple production with mean of 13 years. This implied that most of the pineapple farmers had been into pineapple production over a long period of time which may necessitate the need to re-train farmers on improved techniques of production to increase output as farmers might still be attached to their regular old techniques of production. However farmers with more years of farming experience tend to be more efficient in production (Kudi et al, 2008). Results revealed, most of the pineapple farmers were producing on a small scale (0.1-1ha farm holdings) with an average farm size of 0.89 ha. The farmers used an average of 73 man days of labour/ha, 3765 pineapple suckers/ha and $463 \mathrm{~kg}$ of fertilizer/ha to produce an average pineapple yield of $21,658 \mathrm{~kg} / \mathrm{ha}$ per production cycle (table 2).

\section{Stochastic production frontier estimation}

\subsection{Production factors}

Results from table 4 revealed that the coefficients of variables related to quantity of suckers $\left(X_{1}\right)$ and total quantity of labour used $\left(X_{3}\right)$ were positive and statistically significant at 5\% while farm size $\left(X_{4}\right)$ was significant at $1 \%$ implying that these variables were the factors affecting yield of pineapple farmers in Osun State and any increase in the value of these variables would increase pineapple production. This results conform to findings of Amarasuriya et al. (2010) in technical efficiency in intercropped pineapple production in Kurunegala District where the estimated maximum likelihood coefficients for land, plant density (which depends on the quantity of suckers used) and labour were positive and found to have significant impact on the technical efficiency of pineapple production in the study area. Okon et al. (2010) also reported in their study that quantity of planting materials, total quantity of labour used and farm size significantly affect technical efficiency of Garden egg farmers in Imo state. However the coefficient of fertilizer $\left(X_{2}\right)$ was negative and not statistically significant which contradicts the findings of Amasuriya et al. (2010) that the coefficient with respect to the quantity of fertilizer used in pineapple production in kurunegala district, Sri lanka was positive and significant. Though it is widely known that the use of fertilizer improves crop production on farms but at some point, adding increasingly more fertilizer improves yield by less per unit of fertilizer and excessive quantities can even reduce yield.

\subsection{Inefficiency factors}

The estimated parameters of the inefficiency model in the stochastic frontier production function of pineapple farmers in Osun State were presented in table 4. Results revealed that the coefficients of parameter estimate related variables such as gender $\left(Z_{1}\right)$, age $\left(Z_{2}\right)$ and years of education $\left(Z_{3}\right)$ were negative while Household size $\left(Z_{4}\right)$

\begin{tabular}{|lrrrr|}
\hline Variable & \multicolumn{1}{c}{ Mean } & Std. deviation & Min. value & Max.value \\
\hline Yield & $21,657.69$ & $9,9824.33$ & $8,372.86$ & $88,696.8$ \\
Sucker & 3764.53 & 190.08 & 3048 & 4572 \\
Fertilizer & 463.02 & 81.24 & 254 & 635 \\
Labour & 72.54 & 12.59 & 50.8 & 129.54 \\
Farm size & 0.89 & 0.31 & 0.2 & 2.4 \\
Age & 54.05 & 7.59 & 30 & 70 \\
Education & 7.49 & 3.87 & 2 & 17 \\
Household size & 5.03 & 2.22 & 1 & 19 \\
Experience & 13.29 & 4.09 & 2 & 30 \\
\hline
\end{tabular}

Source: Field survey, 2013 
and farming experience $\left(Z_{5}\right)$ were positive but not statistically significant on technical efficiency of pineapple farmers in the study area. This implied that these socioeconomic/inefficiency factors were less important in determining the technical efficiency of the pineapple farmers in the study area unlike the production factors. The results were consistent with the findings of Idris et al. (2013). He found that farmers' age, farming experience and education were not significantly related to technical efficiency of pineapple farmers in Samarahan, Malaysia. Amasuriya et al. (2010) also reported in his study on the technical efficiency in intercropped pineapple production in Kurunegala district, Sri lanka that education, age and number of family members (household size) did not have any significant impact on efficiency of the pineapple producers in the study area. Though the inefficiency variables were not significant, the sign of the inefficiency model of the stochastic frontier production function had important implications on technical efficiency. The positive coefficients for household size $\left(\mathrm{Z}_{4}\right)$ and farming experience $\left(\mathrm{Z}_{5}\right)$ indicated that these factors decrease the technical efficiency of the pineapple farmers while negative coefficients for gender $\left(Z_{1}\right)$, age $\left(Z_{2}\right)$ and years of education $\left(Z_{3}\right)$ indicated these factors lead to increase in technical efficiency of pineapple farmers in the study area.

\subsection{Correlation matrix}

The correlation matrix for yield and socioeconomic variables was computed to verify whether the statistical insignificance of the socioeconomic variables on the technical efficiency of the pineapple farmers in the study area may be attributed to high multi-colinearity of the parameters. In using the correlation matrix to test for multicollinearity among variables, it is assumed that any pair of correlation coefficient that is more than 0.70 would pose serious multi-colinearity problems (Adeniyi, 2013). Thus, as shown in table 3, none of the variable pair of the correlation coefficient posed serious multi-colinearity problem that could be responsible for the insignificance of the parameters. However, table 3 showed in order of importance that household size $>$ gender $>$ years of experience $>$ age $>$ years of education were all positively correlated with yield in the study area.

\subsection{Variance parameters}

Table 4 revealed that the estimated sigma squared $\left(\sigma^{2}=4.38\right)$ was statistically different from zero at $5 \%$ level of significance. This indicated a good fit of the model and the correctness of the specified distributional assumptions of the composite error term. The variance ratio $($ gamma $=0.81)$ which can be interpreted to mean the differences between actual (observed) and frontier output are dominated by technical inefficiency indicates that systematic influences that are unexplained by the production function are the dominant sources of random error (Okon et al., 2010). The results from table 4, revealed that about $81 \%$ of the variation in yield among Pineapple farmers in the study area was due to the differences in their technical efficiencies while $19 \%$ would be due to random effects.

\subsection{Elasticity of production and returns to scale (RTS)}

Results from table 4 revealed that a unit increase in the number of suckers used will correspond to a more than proportionate increase in pineapple yield by $1.3 \%$. While a unit increase in the quantity of labour and farm size (ha) used will lead to a less than proportionate increase in pineapple yield by $0.50 \%$ and $0.50 \%$ respectively. A unit increase in the quantity of fertilizer used corresponds to a less than proportionate decrease in pineapple yield by $0.22 \%$. The value of returns to scale, which is the summation of the elasticity of production of the variables involved in pineapple production was 2.1 (table 4). This implied increasing returns to scale, indicating that an increase in the use of all specified production inputs

\begin{tabular}{|c|c|c|c|c|c|c|}
\hline Variables & Output & Gender & Age & Years of education & Household size & Years of experience \\
\hline Output & 1 & & & & & \\
\hline Gender & 0.072 & 1 & & & & \\
\hline Age & 0.048 & -0.148 & 1 & & & \\
\hline Years of education & 0.015 & 0.091 & -0.266 & 1 & & \\
\hline Household size & 0.147 & -0.031 & 0.353 & -0.110 & 1 & \\
\hline Years of experience & 0.063 & 0.048 & 0.4548 & -0.214 & 0.334 & 1 \\
\hline
\end{tabular}

Source: Computed from survey data, 2013.

Table 3: Correlation matrix for yield and socio-economic characteristics of pineapple farmers. 


\begin{tabular}{|lcccc|}
\hline Variables & Parameter & Coefficient & Standard error & T-ratio \\
\hline Production function & & & & \\
Constant term & $\beta_{0}$ & 0.90811814 & 1.3993742 & 0.6489459 \\
Number of suckers used $\left(\mathrm{X}_{1}\right)$ & $\beta_{1}$ & 1.32686020 & 0.5378930 & $2.4667736^{* *}$ \\
Quantity of fertilizer used $\left(\mathrm{X}_{2}\right)$ & $\beta_{2}$ & -0.21939091 & 0.1554340 & -1.4114727 \\
Total quantity of labour used $\left(\mathrm{X}_{3}\right)$ & $\beta_{3}$ & 0.50447788 & 0.2175497 & $2.3189092^{* *}$ \\
Farm size $\left(\mathrm{X}_{4}\right)$ & $\beta_{4}$ & 0.50304837 & 0.09705917 & $5.1829043^{* * *}$ \\
Inefficiency model & & & \\
Constant term & $\mathrm{Z}_{0}$ & 0.51954112 & 0.42943420 & 1.2098271 \\
Gender & $\mathrm{Z}_{1}$ & 0.01062548 & 0.04856982 & 0.21876713 \\
Age & $\mathrm{Z}_{2}$ & -0.04968262 & 0.17875332 & -0.27793957 \\
Years of education & $\mathrm{Z}_{3}$ & -0.01462249 & 0.01508117 & -0.96958601 \\
Household size & $\mathrm{Z}_{4}$ & 0.023281710 & 0.04039317 & 0.57637744 \\
Years of experience & $\mathrm{Z}_{5}$ & 0.135570150 & 0.01446367 & 0.93731477 \\
Variance parameters & & & \\
Sigma squared & $\sigma^{2}$ & 4.3796927 & 4.1158574 & $1.6401022^{* *}$ \\
Gamma & & 0.81362837 & 0.19528440 & $4.1663767 * * *$ \\
Log likelihood function & & 90.715764 & & \\
LR test & & 13.608830 & & \\
No. of observations & 120 & & & \\
\hline
\end{tabular}

Note: $* * *=$ significant at $1 \%, * *=$ significant at $5 \%$ level of probability, $*=$ significant at $10 \%$ level of probability

Source: Computer printout of FRONTIER 4.1c, using field survey data, 2013.

Table 4: Maximum likelihood parameter estimates of stochastic production frontier of pineapple producers in Osun State, Nigeria.

\begin{tabular}{|lccccc|}
\hline Inputs & MPP & MVP & $\begin{array}{c}\text { Unit price } \\
\text { of input }\left(\mathrm{Nr}_{\mathrm{xi}}\right)\end{array}$ & MFC & Efficiency ratio \\
\hline Sucker & 1.3269 & 66.345 & 20 & 26.538 & 2.50 \\
Fertilizer & -0.2194 & -10.97 & 140 & -30.716 & 0.34 \\
Labour & 0.5045 & 25.23 & 1500 & 756.75 & 0.03 \\
Land & 0.5030 & 25.15 & 4029 & $2,026.59$ & 0.012 \\
\hline
\end{tabular}

Source: Field survey, 2013

Table 5: Relative efficiency of input use.

would result in more than proportionate increase in the yield of pineapple.

\subsection{Resource use efficiency}

The result of the resource-use efficiency was given in table 5. The unit farm gate price of pineapple was N 50.00/kg. Result indicated that suckers were under-utilized as MVP > MFC while fertilizer, labour and land were over-utilized as MVP $<\mathrm{MFC}$. This means that increase in the use of suckers will lead to further increase in output. Specifically for every amount spent on suckers, the returns from pineapple will increase by $\mathrm{N} 2.50$. However for production inputs with MVP $<$ MFC, there is need to cut down the level of resource use until the marginal value product and the marginal factor cost of each resource are at equilibrium in order to attain optimal allocation of the resources (i.e. $\mathrm{MVP}=\mathrm{MFC}$ ).

\subsection{Technical efficiency estimates}

Table 6 showed the frequency distribution of the pineapple farmers in the study area according to their Technical efficiencies in production. Results revealed, estimated technical efficiencies of the pineapple farmers ranged between 0.69 and 0.98 with a mean technical efficiency of 0.93 . This implied that on the average, farmers are able to obtain $93 \%$ of potential yield from a given mix of production inputs. 


\begin{tabular}{|lcc|}
\hline Efficiency level & Frequency & Percentage \\
\hline $0.61-0.70$ & 1 & 0.83 \\
$0.71-0.80$ & 7 & 5.83 \\
$0.81-0.90$ & 23 & 19.17 \\
$0.91-1.00$ & 89 & 74.17 \\
Total & 120 & 100.0 \\
Minimum value & 0.69 & 0 \\
Maximum value & 0.98 & 6.7 \\
Mean technical efficiency & 0.93 & 75.8 \\
\hline
\end{tabular}

Source: Field survey, 2013

Table 6: Frequency Distribution of Technical Efficiency of Pineapple farmers in Osun State, Nigeria.

In the short run, there is scope for increasing Pineapple yield by $7 \%$ through the adoption of the techniques and technology employed by the most technically efficient Pineapple farmer in the study area at no additional cost. The implications of the result is that an average Pineapple farmer in the study area could realize $6 \%$ cost savings $\{$ i.e. $1-(0.93 / 0.98) * 100\}$ to achieve the technical efficiency level of his most efficient counterpart while the most technically inefficient Pineapple farmer in the study area could realize $30 \%$ cost savings $\{$ i.e. $1-(0.69 / 0.98) * 100\}$.

\section{Conclusion}

The study analyzed the technical efficiency of pineapple production in Osun state, Nigeria using stochastic frontier production function approach and resource use efficiency. Results indicated that production factors such as quantity of suckers, labour and farm size used in pineapple production were significant and more important in determining the technical efficiency of the pineapple farmers in the study area. The return to scale was 2.1 . This indicated stage 1 of the productivity zone showing an inefficient allocation and utilization of resources. Resource use efficiency indicated underutilization of suckers and overutilization of labour, fertilizer and farm land used in pineapple production. Despite the fact that about $90 \%$ of the farmers in the study were technically efficient, there is scope for improving technical efficiciency and productivity through investments in research and development and adoption of techniques and technology at no additional cost. The study recommends that farmers should cut down the use of resources that were over utilized and increase the quantity of suckers used in the production of the commodity in order to attain optimal allocation and utilization of resources for enhanced productivity.

Corresponding author:

Olayinka Adegbite

National Horticultural Research Institute, P.M.B. 5432, Idi-ishin, Ibadan, Nigeria

Phone:+2348025387226, E-mail: olayinkadegbite@gmail.com

\section{References}

[1] Adenikinju, A. F. Productivity Performance in Developing Countries: Country. Case studies Nigeria. 2005. [Online]. Available: http:/www.unido.org/fileadmin/usermedia/Publications/ Pubfree/productivity performance in DCsNigeria.pdf [Accessed: 2 Dec. 2012].

[2] Adeniyi, O. R. Socio-economic Analysis of Subsistence Farming Practices in South-Western Nigeria. Sustainable Agriculture Research. 2013, 2(1):104-111. ISSN 1927-050X.

[3] Adepoju, A. A. Technical Efficiency of Egg Production in Osun State. International Journal of Agricultural Economics \& Rural Development. 2008, 1(1): 7-14. [Online ]. Available: http://www.lautechaee-edu.com/journal/ijaerd1/ijaerd-1.2edition.pdf [Accessed: 25 Sep. 2013 ].

[4] Adesope, A. A. A., Awoyinka, Y. A., Babalola, D. A. Economic Analysis of Group Marketing of Pineapple in Selected Markets of Osun-State, Nigeria. Acta Satech. 2009, Vol.3, 1, p. 47 - 52. ISSN 1597-1007.

[5] Aigner, D., Lovell, C. A. K., Schmidt, P. Formulation and Estimation of Stochastic Frontier Production Function Models, Journal of Econometrics, 1977, 6(2):21-37. ISSN 0304-4076.

[6] Amao, I. O., Adebisi-Adelani, O., Olajide-Taiwo, F. B., Adeoye, I. B., Bamimore, K. M., Olabode, I. Economic Analysis of Pineapple Marketing in Edo and Delta States Nigeria. Libya Agriculture Research Center Journal International. 2011, Vol. 2, 5, p. 205-208. ISSN 2219-4304. 
[7] Amarasuriya, M. T. C, Edirisinghe, J., Patalee, M. A. B. Technical Efficiency in Intercropped Pineapple Production in Kurunegala District. Journal of Food and Agriculture, 2010, Vol.3, 1-2, p. 50-56. ISSN 1800-4288.

[8] Anyanwu, S. O, Obasi, P. C. Comparative Analysis of Land Productivities in Low and High External Input Technology Agriculture in Imo State, Nigeria. Acta Agronomica Nigeriana. 2010, Vol. 10, 1, p. 15-21. ISSN: 0795-9982.

[9] Baruwa, O. I. Profitability and Constarints of Pineapple Production in Osun State, Nigeria. Journal of Horticultural Research, 2013, Vol. 21, 2, p. 59-64. ISSN 2300-5009.

[10] Battesse, G. E., Corra, C. S. Estimation of production frontier model: with application to the pastoral zone of Eastern Australia. Australian Journal of Agricultural Economics. 1977, Vol. 21, p. 169-179. ISSN 1467-8489.

[11] Battese, G. E., Coelli, T. J. A Model for Technical Inefficiency Effects in a Stochastic Frontier Production Function for Panel Delta. Empirical Economics. 1995, Vol. 20, p. 325-335. ISSN 0377-7332, E-ISSN 1435-8921.

[12] Cesaro, L., Marongiu, S., Arfini, F., Donati, M., Capelli, M. G. Methodology for Analysing Competitiveness, Efficiency, and Economy of Scale. Use and Application of DEA. Farm Accounting Cost Estimation and Policy Analysis of Europrean Agriculture. 2009, FACEPA Deliverable No. D5. 1.3.

[13] Coelli, T. J. A Guide to Frontier Version 4.1 Computer Program for Stochastic Frontier Function and Cost Function Estimation. Unpublished Paper, Department of Econometrics, University of New England, Armidale, 1996, NSW2351, Australia. p. 32.

[14] Coelli, T. J., Battese, G. E. Identification of Factors which Influence the Technical Inefficiency of Indian Farmers, Australian Journal of Agricultural and Resource Economics. 1996, Vol. 40, 2 , p. 103-128. ISSN 1364-985X, E-ISSN 1467-8489.

[15] Fakayode, S. B., Rahji, M. A. Y., Adeniyi, S. T. Economic Analysis of Risks in Fruits and Vegetable Farming in Osun State, Nigeria. Bangladesh Journal of Agricultural Research. 2012, Vol. 37, 3, p. 473-491. ISSN 0258-7122

[16] FAOSTAT. 2012. [Online] Available: http://www.fao.org [Accessed: 29 $9^{\text {th }}$ December, 2012].

[17] Fawole, O. P. Pineapple Farmers' Information Sources and Usage in Nigeria. Bulgarian. Journal of Agricultural Science. 2008, Vol. 14, 4, p. 381-389. ISSN 1310-0351.

[18] Gil, J. M., Lambarra, F., Serra, T. Are The Spanish Citrus Farms Efficient? Paper prepared for presentation at the Mediterranean Conference of Agro- Food Social Scientists. 103 ${ }^{\text {rd }}$ EAAE Seminar 'Adding Value to the Agro- Food Supply Chain in the Future Euromediterranean Space'. Barcelona, Spain, April 23 $3^{\text {rd }}-25^{\text {th }}, 2007$.

[19] Idris, N. D. M., Siwar, C., Talib, B. Determinants of Technical Efficiency on Pineapple Farming, American Journal of Applied Sciences (AJAS). 2013, Vol. 4, 10, p. 426-431. ISSN: 1546-9239

[20] Jondrow, J., Lovell, C. A. K., Materov, I. S., Schmidt, P. On the Estimation of Technical Inefficiency in the Stochastic Frontier Production Function Model. Journal of Econometrics. 1982, 19, p. 233 - 238. ISSN 0304-4076.

[21] Joy, P. P. Benefits and Uses of Pineapple. Pineapple Research Station (Kerala Agricultural University), Vazhakulam-686 670, Muvattupuzha, Ernakulam, Kerala, India. 2010. [Online]. Available: http://www.kau.edu/prsvkm [Accessed: 13 ${ }^{\text {th }}$ September, 2013].

[22] Kudi, T. M., Usman, I., Akpoko, J. G., Banta, A. L. Analysis of the Impact of National Fadama Development Project II (NFDP II) in Alleviating Poverty Among Farmers in Giwa Local Government of Kaduna State Nigeria. Ozean Journal of Applied Sciences. 2008, Vol.1, 1, p. 10-24. ISSN 1943-2429. 
[23] Lawal M. A. Efficiency of sweet orange production among small scale farmers in Osun State, Nigeria. African Journal of General Agriculture. 2007, 3(2):127-132. A Publication of the African Studies on Population and health. [Online]. Available: http://www.klobex.org/ajga2.htm. [Accessed: $25^{\text {th }}$ September, 2013].

[24] Meeusen, W., Van den Broeck, J. Efficiency Estimation from Cobb-Douglas Production Functions with Composed Error, International Economic Review 1977, 18, p. 435-444. ISSN 1468-2354.

[25] Michael, O. F. Measuring Technical Efficiency of Yam Farmers in Nigeria. A Stochastic Parametric Approach. Agricultural Journal. 2011, 6, Vol. 20, p. 40-46. ISSN 1816-9155.

[26] National Population Commission (NPC). Nigerian population census figures. Population Development. Rev., 2006, Vol. 33, 1, p. 206-210. Online ISSN: 1728-4457.

[27] Obasi, P. C., Ukoha, A. H., Ukewuihe, I. S., Chidiebere-Mark, N. M. Factors Affecting Agricultural Productivity among Arable Crop Farmers in Imo State, Nigeria. American Journal of Experimental Agriculture. 2013, Vol. 3, 2, p. 443-454. ISSN: 2231-0606.

[28] Ogunlari, K. A Meta-Analysis of Technical Efficiency in Nigerian Agriculture. Contributed Paper prepared for presentation at the International Association of Agricultural Economists Conference, Beijing, China, August 16-22, 2009.

[29] Ogunniyi, L. T., Oladejo, J. A. Technical Efficiency of tomato production in Oyo State, Nigeria. Agricultural Science Research Journal. 2011, Vol. 1, 4, p. 84 - 91. ISSN-L:2026-6073.

[30] Okon, U. E., Enete, A. A., Bassey, N. E. Technical Efficiency and its Determinants in Garden Egg (Solanum Spp) Production In Uyo Metropolis, Akwa Ibom State, Nigeria. Field Actions Science Report. 2010, Special Issue 1. Urban Agriculture. [Online]. Available: http://factsreports.revues. org/458 [Accessed: 10 Jan. 2014].

[31] Oladapo, M. O., Mommoh, S., Yussuf, S., Awoyinka, Y. Marketing Margin and Spatial Pricing Efficiency of Pineapple in Nigeria, Asian Journal of Marketing. 2007, Vol. 1, 1, p. 14-22. ISSN 1819-1924.

[32] Oluyole, K. A., Dada, O. A., Oni, O. A., Adebiyi, S., Odumole, O. O. Farm Labour Structure and its Determinants among Cocoa Farmers in Nigeria. American Journal of Rural Development. 2013, Vol. 1, 1, p. 1-5. ISSN 2333-4762.

[33] Osun State Government. 2004. [Online]. Available: http//www.osunstate.gov.ng/osun_profile.asp [Accessed: 12 ${ }^{\text {th }}$ September, 2013].

[34] Osun state Agriculture. 2009. [Online]. Available: http:// www.osunstate.gov.org [Accessed: 25 ${ }^{\text {th }}$ September, 2013].

[35] Ullah, M. H. Some Aspects of Economics of Citrus Cultivation. The Punjab Fruit Journal Printing Press Limited. Bull Road, Lahore 1980, Vol. XXVI - VII, 90-99, p. 42-45/431.

[36] Xu, X., Jeffrey, S. Rural Efficiency, Technical Progress and Modern Economic Evidence from Rice Production in China. Staff paper 95-02. Department of Rural Economy, Faculty of Agriculture, Forestry and Home Economics, University of Edmonton, Canada, 1995.

[37] Yao, S., Liu, Z. Determinants of Grain Production and Technical Efficiency in China. Journal of Agricultural Economics. 1998, Vol. 49, 2, p. 171 - 184. ISSN 1477-9552. 